\title{
Pelatihan Penulisan Artikel Ilmiah bagi Guru-Guru MGMP Bahasa Indonesia SMP se-Kota Pekanbaru
}

\author{
Alber $^{1}$, Erni $^{2}$, Rika Ningsih ${ }^{3}$, Hermaliza ${ }^{4}$ \\ Universitas Islam Riau, alberuir@edu.uir.ac.id \\ Universitas Islam Riau, erni@edu.uir.ac.id \\ Universitas Islam Riau, rikaningsih@edu.uir.ac.id \\ Universitas Islam Riau, hermaliza@edu.uir.ac.id
}
2021 by the authors. Submitted for possible open access publication under the terms and conditions of the Creative Commons Attribution-ShareAlike 4.0 International License-(CC-BY-SA) (https://creativecommons.org/licenses/by-sa/4.0/)
do) DOI : http://dx.doi.org/10.30983/dedikasia.vli2.5146

\section{ARTICLE INFO \\ Submit : :21 Agustur 2021 \\ Revised : 17 November 2021 \\ Accepted : 30 Desember 2021}

Keywords:

Training; Scientific Article Writing
International License-(CC-BY-SA)

(https://creativecommons.org/licenses/by-sa/4.0/)

doi $\underline{\text { http://dx.doi.org/10.30983/dedikasia.vli2.5146 }}$

\section{ABSTRACT}

The implementation of this community service departs from the many complaints of teachers who have difficulty in writing scientific articles. In fact, research activities and writing scientific articles are required to be carried out by teachers in order to improve the pedagogic quality of educators. Based on this, this service needs to be carried out seriously to the stage of writing scientific articles and publishing them. Law Number 14 of 2005 concerning teachers and lecturers states firmly that teachers are required to have academic qualifications, competencies, educator certificates, and so on. With the productiveness of teachers carrying out scientific article writing activities, they can increase teacher professionalism, increase teacher competence, increase teacher confidence, and enable teachers to actively develop their knowledge and skills. The results of PkM, community service participants, in this case Indonesian junior high school MGMP teachers throughout Pekanbaru City, can understand, write scientific articles, and are able to publish their articles in reputable journals.

This is an open access article under the CC-BY-SA license

\section{Introduction}

Undang-undang Nomor 14 Tahun 2005 tentang Guru dan Dosen pada Pasal 1 menjelaskan bahwa guru adalah pendidik profesional dengan tugas utama mendidik, mengajar, membimbing, mengarahkan, melatih, menilai, dan mengevaluasi pada pendidikan anak usia dini jalur pendidikan formal, pendidikan dasar, dan pendidikan menengah. Agar menjadi pendidik profesional yang sesuai dengan undang-undang tersebut butuh usaha yang tidak mudah. Guru wajib meningkatkan kompetensinya terlebih dahulu. Salah satu cara meningkatkan kompetensi tersebut adalah dengan melakukan riset dan menuliskannya dalam bentuk karangan ilmiah (Depdiknas, 2015).

Dalam jabatan profesi, penulisan karangan ilmiah menjadi syarat wajib bagi guru karena bagian dari kegiatan pengembangan keprofesian berkelanjutan. Kegiatan penulisan karangan ilmiah dinilai angka kreditnya sehingga berpengaruh terhadap kenaikan jabatan guru tersebut. Itu terjadi karena menulis karangan ilmiah dan memublikasikannya merupakan salah satu kelengkapan berkas kenaikan pangkat guru. Jadi, penulisan karangan ilmiah merupakan salah satu implementasi Undang-Undang Nomor 14 Tahun 2005 tentang Guru dan Dosen, pada pasal 10 ayat (1) yang 
menyatakan "Kompetensi guru sebagaimana dimaksud dalam Pasal 8 meliputi kompetensi pedagogik, kompetensi kepribadian, kompetensi sosial, dan kompetensi profesional yang diperoleh melalui pendidikan profesional".

Kegiatan penulisan karangan ilmiah itu meliputi melakukan dan menulis penelitian kemudian memublikasikannya baik secara daring maupun luring. Agar kegiatan ini berjalan lancar, dibutuhkan banyak syarat. Syarat itu antara lain penulis harus menguasai sistematika karangan ilmiah, tata tulis karangan ilmiah, dan prosedur meneliti sebagaimana harusnya. Ilmu dan keterampilan untuk itu tidak diperoleh dalam sehari. Butuh waktu yang panjang dan latihan yang tidak sedikit bagi peneliti untuk menghasilkan penelitian yang layak dan bermanfaat.

Salah satu dari karangan ilmiah itu adalah artikel ilmiah. Menurut Syamsul dalam (Alber \& Hermaliza, 2021:255) artikel merupakan pengungkapan pendapat atau ide tentang suatu tema atau hal yang berisi pandangan, ide, opini, atau penilaian penulis terhadap suatu masalah atau peristiwa yang terjadi di masyarakat. Selanjutnya, Jatmiko et al. (2015:21) menjelaskan artikel ilmiah adalah suatu tulisan yang berisi kumpulan ide, gagasan, dan hasil pemikiran dari seseorang atau sekelompok orang melalui proses penelitian, pengamatan, kajian, dan evaluasi ke dalam suatu bentuk laporan tertulis sesuai dengan sistematika, metode, dan kaidah tertentu. Selain itu, artikel ilmiah juga dimanfaatkan sebagai solusi untuk mengatasi berbagai persoalan yang dihadapi. Menulis artikel ilmiah berguna bagi peneliti untuk berkorespondensi dan bertukar pikiran dengan ilmuan sebidang dari seluruh dunia sehingga solusi yang diharapkan lebih efektif. Pernyataan tersebut senada dengan pendapat (Slameto, 2016:46; Djuroto \& Suprijadi, 2005; Marwoto et al., 2013:112; Dewi et al., 2017:8; Supriyadi, 2013; Suyanto \& Asep, 2014:34; dan Maimunah, 2007:91).

Sistematika penulisan artikel ilmiah biasanya bersifat selingkung. Dengan kata lain, setiap jurnal ilmiah atau konferensi memiliki sistematika masing-masing. Akan tetapi, secara umum semuanya memiliki kesamaan pada bagian-bagian utama penulisan seperti, judul, abstrak, kata kunci, pendahuluan, metodologi, hasil dan pembahasan, simpulan, acknowledgment (jika ada), dan refensi (Jatmiko et al., 2015:85; Slameto, 2015:48; ZA, 2020:8). Penulisan artikel ilmiah ini sangat bermanfaat bagi guru. Penulisan artikel ilmiah dapat melatih menemukan metode baru dengan melakukan observasi dan eksperimen lebih lanjut untuk memahami metode secara mendalam. Penulisan artikel ilmiah juga dapat meningkatkan kemampuan investigasi sebab tuntutan untuk menyelidiki suatu objek, memahami intinya, dan memublikasikan temuan tersebut. Selain iu, penulisan artikel ilmiah dapat mengembangkan teknik baru berdasarkan eksperimen dan melatih pemikiran kritis sebab proses penelitian itu tidak hanya berkaitan dengan satu bidang ilmu saja. Selanjutnya, penulisan artikel ilmiah dapat melatih pemikiran yang logis dan kemampuan berargumentasi karena artikel yang dihasilkan dari proses penelitian membutuhkan klaim dan harus disertai dengan alasan dan bukti yang konkret.

Selain membuat karya ilmiah, guru-guru juga dituntut untuk mempublikasikan karya ilmiahnya tersebut. Publikasi ilmiah merupakan hasil penelitian atau gagasan ilmu bidang 
pendidikan formal. Publikasi ini dapat dimaknai sebagai upaya untuk menyebarluaskan suatu karya pemikiran seseorang atau sekelompok orang dalam bentuk laporan penelitian, makalah, buku atau artikel. Karya tulis ilmiah guru dapat dipublikasikan dalam bentuk laporan hasil penelitian atau laporan/gagasan ilmiah yang ditulis berdasar pada pengalaman dan sesuai dengan tugas pokok serta fungsi guru (Kementerian Pendidikan Nasional, Direktorat Pembinaan Pendidik dan Tenaga Kependidikan dalam Noorjannah, 2015:98).

Berdasarkan observasi awal, guru-guru MGMP Bahasa Indonesia SMP se-Kota Pekanbaru masih banyak yang belum paham kaidah penulisan artikel ilmiah yang baik dan benar. Mereka beranggapan bahwa, sistematika penulisan artikel ilmiah sama saja dengan karangan ilmiah lainnya. Selain itu, budaya menulis artikel ilmiah, baru belakangan ini menggeliat di kalangan guru sehingga konsep penulisannya belum mereka kuasai dengan baik. Penulisan artikel ilmiah untuk dipublikasikan menjadi tolok ukur dunia pendidikan dewasa ini sehingga jika seseorang mampu memublikasikan artikel ilmiahnya dalam jurnal internasional bereputasi maka prestisenya naik.

Guna membantu meningkatkan kompetensi guru, dosen-dosen Fakultas Keguruan dan Ilmu Pendidikan Universitas Islam Riau melakukan kegiatan pelatihan penulisan artikel ilmiah bagi guruguru MGMP Bahasa Indonesia se-Kota Pekanbaru. Kegiatan Pengabdian kepada Masyarakat (PkM) ini bermaksud untuk meningkatkan pengetahuan dan pemahaman guru-guru mengenai artikel ilmiah, membantu guru dalam menulis dan memublikasikan artikel ilmiah dalam jurnal nasional atau internasional.

Pelatihan relevan yang dilakukan oleh tim Pengadian kepada Masyarakat (PkM) terdahulu dengan PkM yang penulis lakukan serta sudah dipublikasi di berbagai jurnal. Di antaranya. Pertama, pelatihan yang dilakukan Ngabiyanto et al. (2021) dengan judul "Pelatihan Optimalisasi Model Pembelajaran Student Centered Learning melalui Pelatihan Penulisan Artikel Ilmiah". Tujuan kegiatan ini adalah meningkatkan kompetensi profesional guru, utamanya dalam hal menulis artikel ilmiah. Kompetensi yang masih sulit di- kuasai oleh guru SD N Branjang. UNNES sebagai LPTK harus turut berkon- tribusi dalam mengatasi masalah ini. Salah satu upaya tersebut dalah melalui optimalisasi model pembelajaran student centered learning melalui pelatihan penulisan artikel ilmiah. Hasil kegiatan ini adalah guru-guru SD masih membutuhkan pendampingan dari para ahli dalam mengembangkan kompetensi profesion- alnya, khususnya dalam penulisan artikel ilmiah. Guru-guru SD juga sangat membutuhkan banyak referensi jurnal yang bisa dituju guna mempublikasikan karya ilmiahnya.

Kedua, pelatihan yang dilakukan oleh Marwoto et al. (2013) dengan judul "Peningkatan Kemampuan Menulis Artikel Ilmiah Sains Guru Sekolah Dasar Melalui Kegiatan Pengabdian Masyarakat". Tujuan dilakukan pengabdian masyarakat ini adalah meningkatkan kemampuan menulis artikel ilmiah dalam bidang sains guru SD se-Kecamatan Gunungpati Semarang. Terdapat 3 kegiatan utama pada pengabdian ini, yaitu pertemuan pertama pelatihan menulis artikel ilmiah sains dengan memberikan contoh dan reviu kritis cara menulis. Kegiatan kedua dengan memberikan penugasan untuk membuat poin inti menulis artikel ilmiah sains, dan kegiatan ketiga melakukan 
pendampingan untuk memberikan konsultasi artikel ilmiah sains yang akan dibuat. Berdasarkan evaluasi pelaksanaan kegiatan pengabdian dan hasil uji gain ternormalisasi tampak bahwa telah terjadi peningkatan kemampuan menulis artikel ilmiah sains guru SD melalui kegiatan pengabdian masyarakat ini sebesar 0,74 (kategori tinggi). Kesimpulan dari kegiatan pengabdian masyarakat ini adalah terjadi peningkatan kemampuan menulis artikel ilmiah sains guru SD di Kecamatan Gunungpati Semarang.

Ketiga, artikel yang ditulis Ningsih \& Aviory (2020) dengan judul "Pendampingan Penulisan Artikel Ilmiah Bagi Guru SD”. Tujuan pelatihan adalah untuk menindaklanjuti artikel yang sudah ditulis oleh guru sehingga dapat disesuaikan dengan format penulisan artikel yang ada. Subyek kegiatan adalah guru SDN Tamansari II, dengan target kegiatan meningkatnya pemahaman guru dalam membuat artikel ilmiah. Kegiatan ini diikuti oleh 25 orang guru yang berasal dari SDN Tamansari II. Pendekatan yang digunakan adalah pendekatan klasikal maupun individual. Pendekatan klasikal dilakukan dengan melakukan pelatihan penyusunan artikel ilmiah, dimulai dengan pengenalan tentang jurnal, pengenalan tentang artikel, pemahaman konsep dasar dalam pembuatan artikel, penyusunan artikel ilmiah. Sedangkan pendekatan individual dilakukan saat pendampingan penyusunan artikel ilmiah. Kesimpulan dari kegiatan pendampingan ini adalah meningkatnya pemahaman guru dalam membuat artikel ilmiah serta keinginan dalam membuat artikel cukup tinggi. Kendala umum yang dihadapi guru dalam pembuatan artikel ilmiah adalah kurangnya referensi dalam pembuatan artikel ilmiah, terbatasnya waktu serta kurangnya kreativitas guru dalam menulis artikel ilmiah (hanya terfokus pada penelitian tindakan kelas).

Pelatihan yang penulis lakukan ini relevan dengan ketiga artikel di atas. Namun, terdapat beberapa perbedaan dan persamaan dengan ketiga artikel tersebut. Perbedaan tersebut dapat dilihat dari masing-masing tujuan pelatihan, subjek dan objek pelatihan. Persamaan pelatihan penulis dengan ketiga penelitian di atas adalah sama-sama melakukan pelatihan penulisan artikel ilmiah. Berdasarkan paparan dan fenomena tersebut, penulis tertarik melakukan "Pelatihan Penulisan Artikel Ilmiah Bagi Guru-Guru MGMP Bahasa Indonesia SMP Se-Kota Pekanbaru”.

\section{Methods}

Metode pelaksanaan Pengabdian kepada Masyarakat ini dilaksanakan dengan dengan dua pendekatan yaitu pendekatan klasikal dan pendekatan individu dengan subjek dan objek pelatihan yakni guru-guru MGMP Bahasa Indonesia SMP se-Kota Pekanbaru. Pendekatan klasikal dilakukan dengan dua tahap. Pertama, tim pelaksana datang ke sekolah untuk memberikan pelatihan secara langsung kepada guru-guru MGMP Bahasa Indonesia se-Kota Pekanbaru terkait prosedur penulisan artikel ilimiah. Kedua, Pelatihan dilakukan dengan metode ceramah, tutorial, dan praktik. Sementara itu, pendekatan individual dilakukan dalam kegiatan pendampingan dengan membimbing guru-guru dalam menyusun dan menuliskan artikel ilmiah. Pernyataan tersebut senada dengan pendapat 
(Andriyani et al., 2021:93). Adapun langkah-langkah kegiatan yang dilakukan dalam mencapai tujuan ini adalah seperti berikut ini.

1. Ceramah tentang konseptual penulisan artikel ilmiah dan publikasi karya ilmiah.

2. Ceramah tentang prosedur menyusun artikel ilmiah berdasarkan langkah-langkah yang sesuai dengan teori.

3. Praktik menyusun artikel ilmiah berdasarkan data yang dikumpulkan.

4. Proses pendampingan kepada guru-guru MGMP Bahasa Indonesia se-Kota Pekanbaru untuk meningkatan kualitas proses pembelajaran.

5. Penilaian dan evaluasi kegiatan penulisan artikel ilmiah dilakukan untuk mengetahui pemahaman guru-guru dalam menuangkan ide/gagasannya secara aktual dan objektif dengan mengikuti standar penulisan artikel ilmiah.

\section{Results}

Hasil kegiatan pengabdian kepada masyarakat yang dilaksanakan di aula penerbit Erlangga Pekanbaru berupa pelatihan penulisan artikel bagi guru-guru MGMP Bahasa Indonesia se-Kota Pekanbaru dipaparkan berdasarkan tiga bagian kegiatan yang telah dilaksanakan, di antaranya: Pertama. Tahap Persiapan. Kegiatan ini dimulai dengan mempersiapkan seluruh keperluan pelatihan yang berupa pemberian bahan materi pelatihan dan perlengkapan lainnya yang menunjang pelatihan oleh tim Pengabdian kepada Masyarakat (PkM). Kedua, Tahap Pelaksanaan. Tahap penyampaian informasi untuk materi yang bersifat umum dan teoritis; dalam hal ini tentang pelatihan penulisan artikel. Penyampaian materi disampaikan oleh Alber, S.Pd., M.Pd. sehingga guru-guru MGMP Bahasa Indonesia SMP se-Kota Pekanbaru dapat memahami, menulis artikel ilmiah, serta mampu memublikasikannya artikelnya pada jurnal-jurnal bereputasi. Ketiga, Tahap Pendampingan. Tahap ini diterapkan supaya diperoleh hasil pelatihan berupa produk yang layak untuk dipublikasikan dan pendampingan serta penyampaian materi dilakukan secara intensif. kegiatan pendampingan dengan membimbing guru-guru dalam menyusun dan menuliskan artikel ilmiah.

\section{Discussion}

Publikasi karya ilmiah merupakan sarana yang tepat bagi para peneliti untuk berbagi hasil penelitianya kepada orang lain, sehingga hasil penelitian kita dapat dijadikan referensi bagi para peneliti lainnya. Untuk mampu mempublikasikan hasil-hasil penelitian, para guru harus memiliki wawasan yang sangat luas berkenaan dengan teknik dan cara-cara mempublikasikan karya ilmiah. Melalui kegiatan pelatihan yang akan kami lakukan kali ini, kami akan melatih dan menjembatani para guru untuk mempublikasikan karya ilmiah yang telah dibuatnya. Kegiatan penelitian dan menulis artikel ilmiah dituntut untuk dilaksanakan oleh guru-guru guna peningkatan kualitas pedagogik pendidik. Berdasarkan hal inilah pengabdian ini perlu dilakukan dengan serius sampai pada tahap penulisan artikel ilmiah dan memublikasikannya. Undang-Undang Nomor 14 Tahun 2005 
mengenai guru dan dosen menyatakan dengan tegas bahwa guru wajib memiliki kualifikasi akademik, kompetensi, sertifikat pendidik, dan sebagainya. Dengan produktifnya guru melakukan aktivitas menulis artikel ilmiah dapat meningkatkan profesionalisme guru, meningkatkan kompetensi guru, meningkatkan rasa percaya diri guru, serta memungkinkan guru secara aktif mengembangkan pengetahuan dan keterampilannya.

Selanjutnya, pemberian materi dengan kegiatan diskusi dan pendampingan tersebut mengarahkan kepada setiap peserta untuk bertanya, hal-hal terakait materi nyang tidak dipahami. Berdasarkan hasil dari kegiatan, menunjukkan bahwa pelaksanaan pelatihan ini berhasil dengan baik dan tim PkM sukses menyampaikan materi dengan baik dan benar terlihat dari antusias peserta ketika pelatihan berlangsung.

Setelah pelatihan dilakukan, penilaian dilakukan terhadap jawaban guru-guru MGMP Bahasa Indonesia se-Kota Pekanbaru terdiri dari 12 pertanyaan untuk menjawab kuesioner/angket kepuasan mitra terhadap kegiatan pengadian kepada masyarakat yang diberikan. Penilaian tersebut digunakan untuk mengetahui pengetahuan peserta setelah pelatihan diberikan. Bila terjadi peningkatan yang cukup signifikan dapat dikatakan pelatihan yang diberikan memberikan hasil positif sesuai yang diharapkan. Dengan kata lain bukan besarnya nilai yang diperhitungkan menjadi perhatian utama.

Selanjutnya, kuesioner/angket yang diberikan kepada guru-guru MGMP Bahasa Indonesia se-Kota Pekanbaru terdiri dari 12 pertanyaan dengan hasil sebagai berikut:

1. Materi PkM sesuai dengan kebutuhan Mitra/Peserta

a. Koresponden yang memilih "Sangat Setuju" sebanyak 81,71\%

b. Koresponden yang memilih "setuju" sebanyak 19,29\%

c. Koresponden yang memilih "tidak setuju" sebanyak $0 \%$

d. Koresponden yang memilih "sangat tidak setuju" sebanyak $0 \%$

Berdasarkan hasil presentase pernyataan pertama, dapat dilihat bahwa Materi PkM sesuai dengan kebutuhan Mitra/Peserta. Hal tersebut dapat dilihat dengan pilihan responden sebesar 81,71\% "sangat setuju”, 19,29\% "setuju”, dan pilihan tidak setuju dan sangat tidak setuju $0 \%$. Nilai presentasi juga divisualisasikan melalui gambar 1. 
Gambar l. Materi PkM sesuai dengan kebutuhan Mitra/Peserta

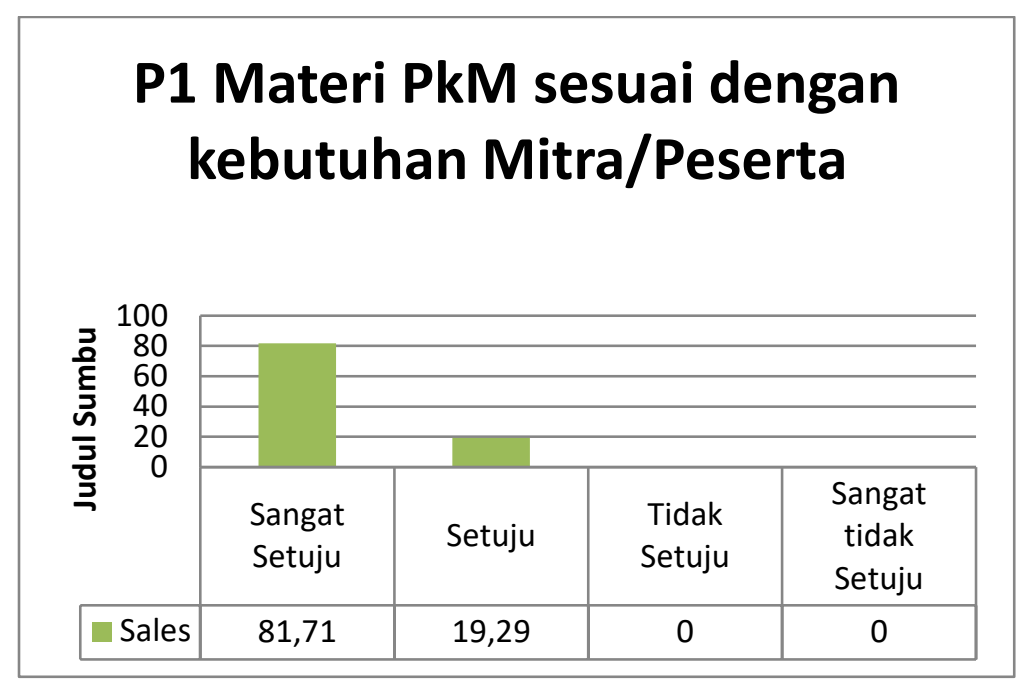

Selanjutnya, pernyataan kedua terkait kegaiatan PkM yang dilaksanakan sesuai harapan mitra, hasil kuesioner sebagai berikut.

2. Kegaiatan PkM yang dilaksanakan sesuai harapan mitra
a. Koresponden yang memilih "Sangat Setuju" sebanyak 59,15\%
b. Koresponden yang memilih "setuju" sebanyak 40,85\%
c. Koresponden yang memilih "tidak setuju" sebanyak 0\%
d. Koresponden yang memilih "sangat tidak setuju" sebanyak $0 \%$

Berdasarkan hasil presentase pernyataan kedua, dapat dilihat bahwa kegaiatan PkM yang dilaksanakan sesuai harapan mitra. Hal tersebut dapat dilihat dengan pilihan responden sebesar 59,15\% "sangat setuju", 40,85\% "setuju", dan pilihan tidak setuju dan sangat tidak setuju $0 \%$. Nilai presentasi juga divisualisasikan melalui gambar 2. 
Gambar 2. kegaiatan PkM yang dilaksanakan sesuai harapan mitra

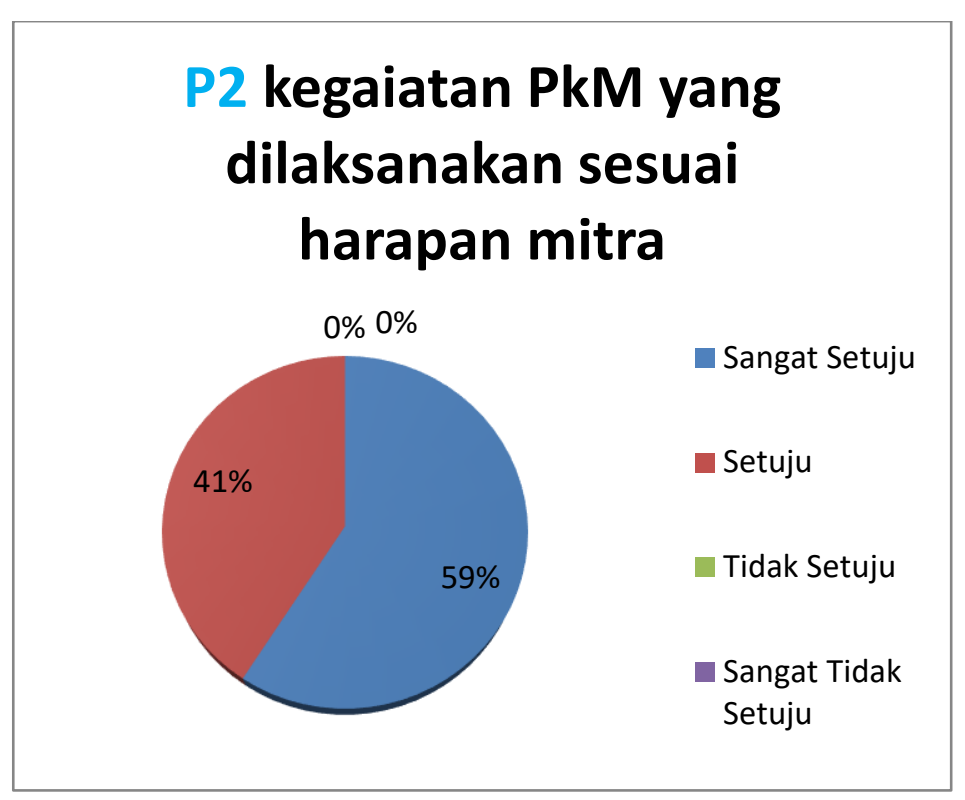

Selanjutnya, pernyataan ketiga terkait cara pemateri menyajikan materi PkM menarik, hasil kuesioner sebagai berikut.

3. Cara pemateri menyajikan materi PkM menarik
a. Koresponden yang memilih "Sangat Setuju” sebanyak $77,24 \%$
b. Koresponden yang memilih "setuju" sebanyak 22,76\%
c. Koresponden yang memilih "tidak setuju" sebanyak $0 \%$
d. Koresponden yang memilih "sangat tidak setuju" sebanyak 0\%

Berdasarkan hasil presentase pernyataan ketiga, dapat dilihat bahwa cara pemateri menyajikan materi PkM menarik. Hal tersebut dapat dilihat dengan pilihan responden sebesar $77,24 \%$ "sangat setuju", 22,76\% "setuju", dan pilihan tidak setuju dan sangat tidak setuju $0 \%$. Nilai presentasi juga divisualisasikan melalui gambar 3. 
Gambar 3. Cara pemateri menyajikan materi PkM menarik

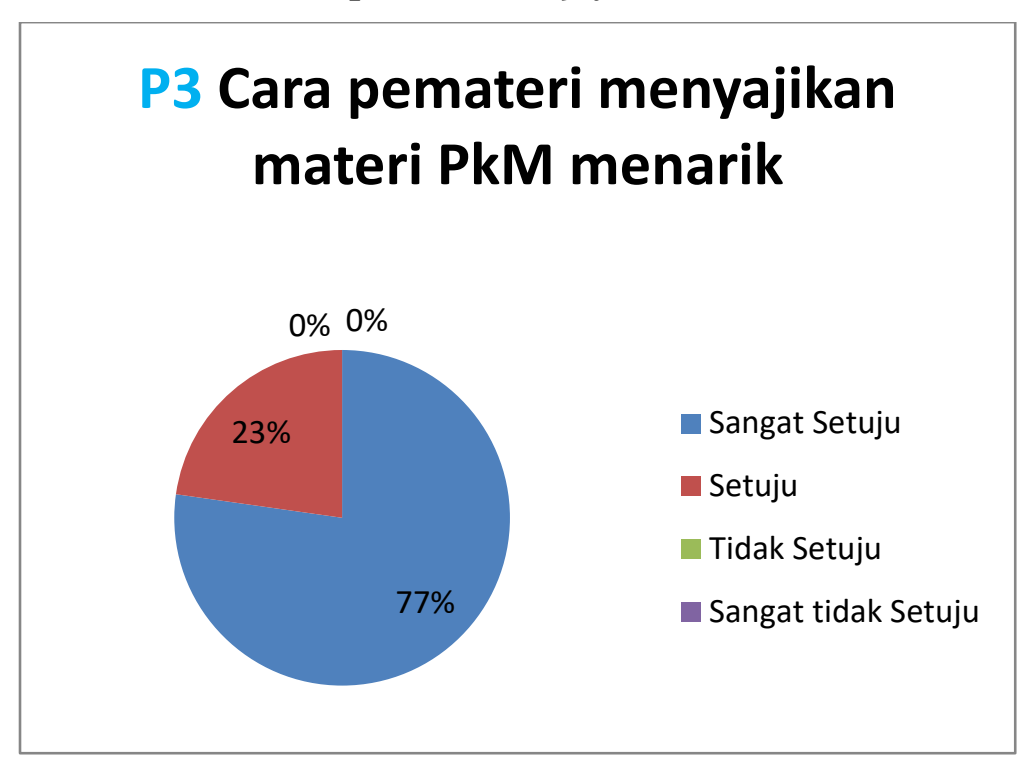

Selanjutnya, pernyataan keempat terkait materi yang disajikan jelas dan mudah pahami, hasil kuesioner sebagai berikut.

4. Materi yang disajikan jelas dan mudah pahami
a. Koresponden yang memilih "Sangat Setuju” sebanyak 85,71\%
b. Koresponden yang memilih "setuju" sebanyak $14.28 \%$
c. Koresponden yang memilih "tidak setuju” sebanyak $0 \%$
d. Koresponden yang memilih "sangat tidak setuju” sebanyak $0 \%$

Berdasarkan hasil presentase pernyataan keempat, dapat dilihat bahwa materi yang disajikan jelas dan mudah pahami . Hal tersebut dapat dilihat dengan pilihan responden sebesar 85,71\% "sangat setuju", $14,28 \%$ "setuju", dan pilihan tidak setuju dan sangat tidak setuju $0 \%$. Nilai presentasi juga divisualisasikan melalui gambar 4.

Gambar 4. materi yang disajikan jelas dan mudah pahami

P4 Materi yang disajikan
jelas dan mudah pahami
- Sangat Setuju
- Setuju
- Tidak Setuju
- Sangat Tidak Setuju


Selanjutnya, pernyataan kelima terkait waktu yang disediakan sesuai untuk penyampaian materi dan kegiatan PkM, hasil kuesioner sebagai berikut.

5. Waktu yang disediakan sesuai untuk penyampaian materi dan kegiatan PkM

a. Koresponden yang memilih "Sangat Setuju" sebanyak 10,28\%

b. Koresponden yang memilih "setuju" sebanyak 59,14\%

c. Koresponden yang memilih "tidak setuju" sebanyak 28,57\%

d. Koresponden yang memilih "sangat tidak setuju" sebanyak 0\%

Berdasarkan hasil presentase pernyataan kelima, dapat dilihat bahwa Waktu yang disediakan sesuai untuk penyampaian materi dan kegiatan PkM. Hal tersebut dapat dilihat dengan pilihan responden sebesar 10,28\% "sangat setuju”, 59,14\% "setuju”, “28,57\%" pilihan tidak setuju dan sangat tidak setuju $0 \%$. Nilai presentasi juga divisualisasikan melalui gambar 5 .

Gambar 5. Waktu yang disediakan sesuai untuk penyampaian materi dan kegiatan PkM

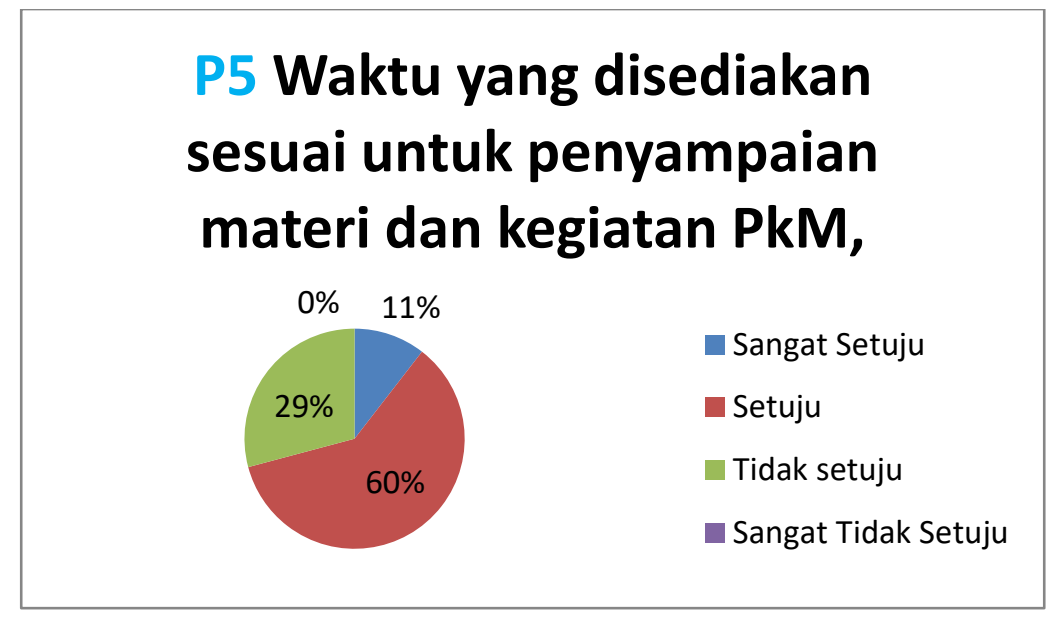

Selanjutnya, pernyataan keenam terkait mitra berminat untuk mengikuti kegiatan PkM selama sesuai kebutuhan Mitra/peserta, hasil kuesioner sebagai berikut.

6. Mitra berminat untuk mengikuti kegiatan PkM selama sesuai kebutuhan Mitra/peserta

a. Koresponden yang memilih "Sangat Setuju" sebanyak 57,14\%

b. Koresponden yang memilih "setuju" sebanyak 42,87\%

c. Koresponden yang memilih "tidak setuju" sebanyak 0\%

d. Koresponden yang memilih "sangat tidak setuju” sebanyak $0 \%$

Berdasarkan hasil presentase pernyataan keenam, dapat dilihat bahwa terkait mitra berminat untuk mengikuti kegiatan PkM selama sesuai kebutuhan Mitra/peserta. Hal tersebut dapat dilihat dengan pilihan responden sebesar 57,14\% "sangat setuju", 42,86\% "setuju" dan pilihan tidak setuju dan sangat tidak setuju 0\%. Nilai presentasi juga divisualisasikan melalui gambar 6. 
Gambar 6. mitra berminat untuk mengikuti kegiatan PkM selama sesuai kebutuhan Mitra/peserta

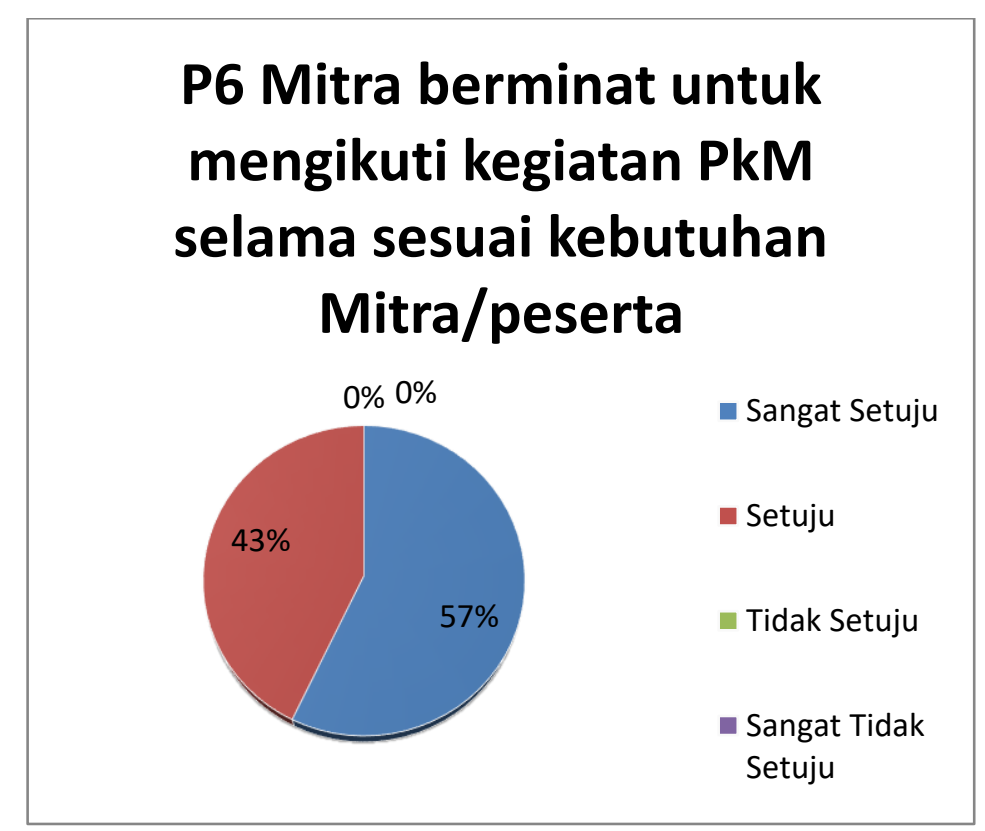

Selanjutnya, pernyataan ketujuh terkait Anggota PkM yang terlibat dalam kegiatan pengabdian masyarakat memberikan pelayanan sesuai dengan kebutuhan, hasil kuesioner sebagai berikut.

7. Anggota PkM yang terlibat dalam kegiatan pengabdian masyarakat memberikan pelayanan sesuai dengan kebutuhan

a. Koresponden yang memilih "Sangat Setuju" sebanyak $72,86 \%$

b. Koresponden yang memilih "setuju" sebanyak 27,14\%

c. Koresponden yang memilih "tidak setuju" sebanyak 0\%

d. Koresponden yang memilih "sangat tidak setuju" sebanyak 0\%

Berdasarkan hasil presentase pernyataan ketujuh, dapat dilihat bahwa Anggota PkM yang terlibat dalam kegiatan pengabdian masyarakat memberikan pelayanan sesuai dengan kebutuhan. Hal tersebut dapat dilihat dengan pilihan responden sebesar 72,86\% "sangat setuju", 27,14\% "setuju" dan pilihan tidak setuju dan sangat tidak setuju $0 \%$. Nilai presentasi juga divisualisasikan melalui gambar 7. 
Gambar 7. Anggota PkM yang terlibat dalam kegiatan pengabdian masyarakat memberikan pelayanan sesuai dengan kebutuhan

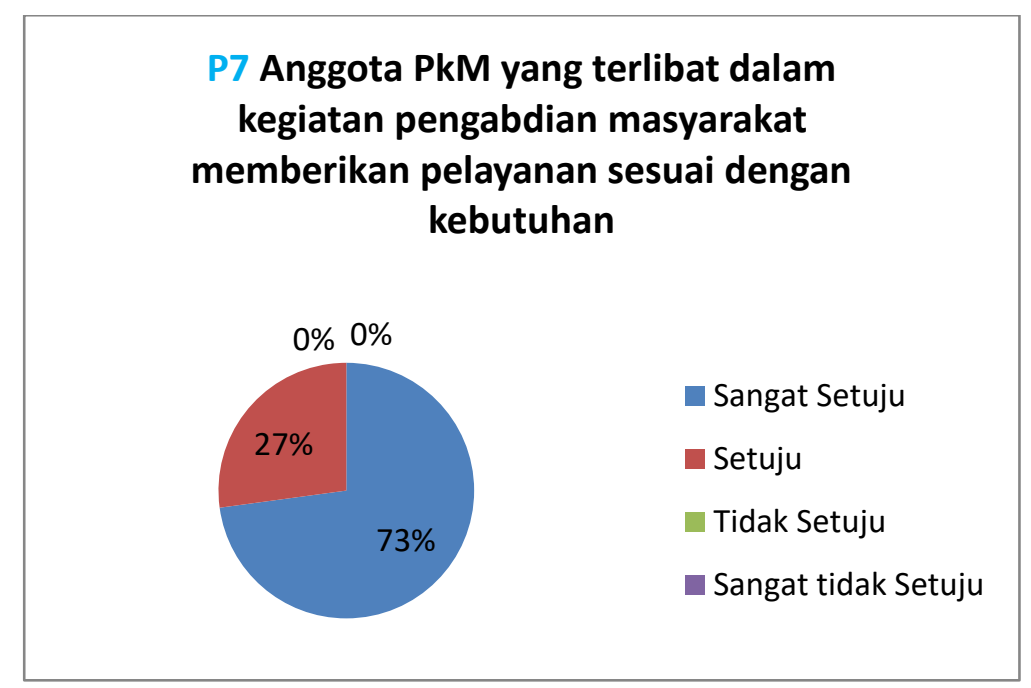

Selanjutnya, pernyataan kedelapan terkait kegiatan PkM dilakukan secara berkelanjutan, hasil kuesioner sebagai berikut.

8. Kegiatan PkM dilakukan secara berkelanjutan

a. Koresponden yang memilih "Sangat Setuju” sebanyak 71,42\%

b. Koresponden yang memilih "setuju" sebanyak 28,57\%

c. Koresponden yang memilih "tidak setuju" sebanyak 0\%

d. Koresponden yang memilih "sangat tidak setuju" sebanyak $0 \%$

Berdasarkan hasil presentase pernyataan kedelapan, dapat dilihat bahwa kegiatan PkM dilakukan secara berkelanjutan. Hal tersebut dapat dilihat dengan pilihan responden sebesar 71,42\% "sangat setuju", 28,57\% "setuju" dan pilihan tidak setuju dan sangat tidak setuju 0\%. Nilai presentasi juga divisualisasikan melalui gambar 8 .

Gambar 8. kegiatan PkM dilakukan secara berkelanjutan

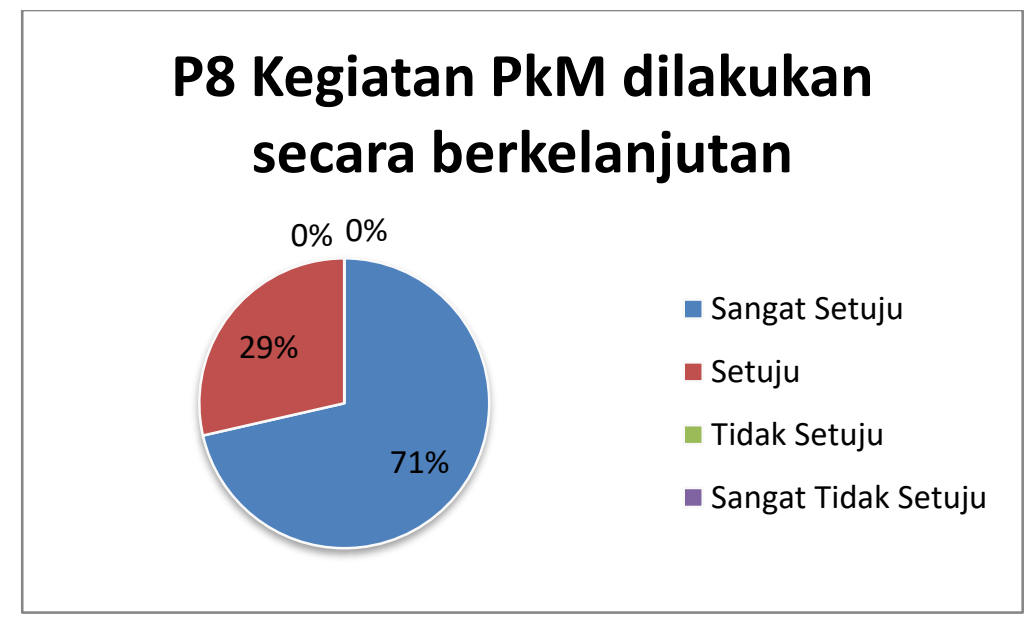


Selanjutnya, pernyataan kesembilan terkait setiap keluhan/pertanyaan/permasalahan yang diajukan ditindaklanjuti dengan baik oleh narasumber/anggota pengabdian yang terlibat, hasil kuesioner sebagai berikut.

9. Setiap keluhan/pertanyaan/permasalahan yang diajukan ditindaklanjuti dengan baik oleh narasumber/anggota pengabdian yang terlibat,
a. Koresponden yang memilih "Sangat Setuju" sebanyak 25
b. Koresponden yang memilih "setuju" sebanyak $75 \%$
c. Koresponden yang memilih "tidak setuju" sebanyak 0\%
d. Koresponden yang memilih "sangat tidak setuju" sebanyak 0\%

Berdasarkan hasil presentase pernyataan kesembilan, dapat dilihat bahwa setiap keluhan/pertanyaan/permasalahan yang diajukan ditindaklanjuti dengan baik oleh narasumber/anggota pengabdian yang terlibat. Hal tersebut dapat dilihat dengan pilihan responden sebesar 25\% "sangat setuju", $75 \%$ "setuju" dan pilihan tidak setuju dan sangat tidak setuju 0\%. Nilai presentasi juga divisualisasikan melalui gambar 9.

Gambar 9. Setiap keluhan/pertanyaan/permasalahan yang diajukan ditindaklanjuti dengan baik oleh narasumber/anggota pengabdian yang terlibat

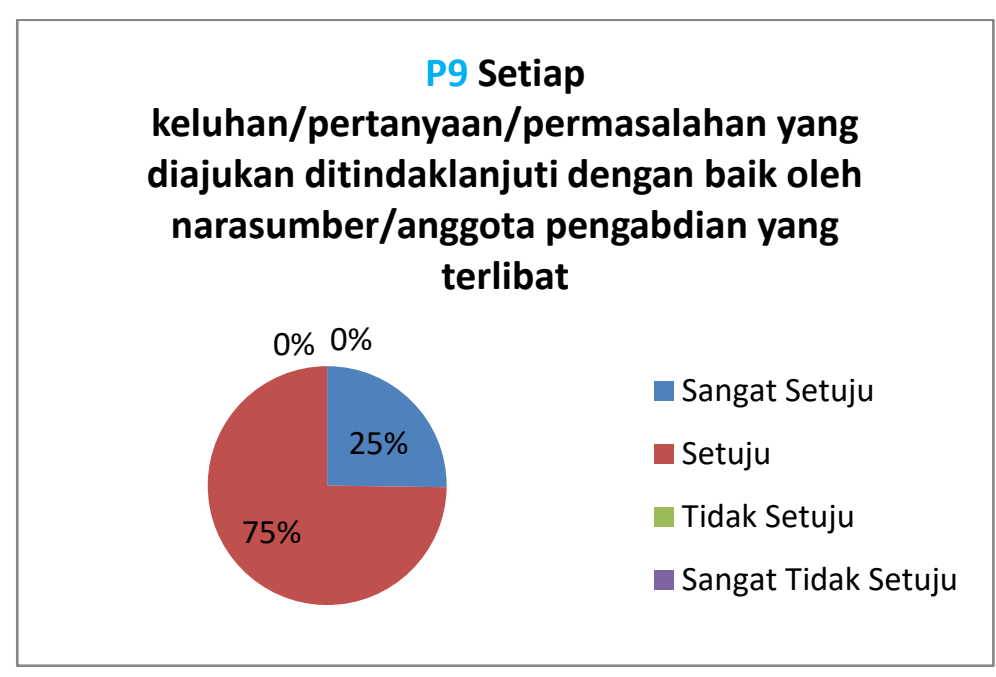

Selanjutnya, pernyataan kesepuluh terkait Mitra mendapatkan manfaat langsung dari kegiatan PkM yang dilakasanakan, hasil kuesioner sebagai berikut.

10. Mitra mendapatkan manfaat langsung dari kegiatan PkM yang dilakasanakan
a. Koresponden yang memilih "Sangat Setuju" sebanyak 28,57\%
b. Koresponden yang memilih "setuju" sebanyak $71,43 \%$
c. Koresponden yang memilih "tidak setuju" sebanyak $0 \%$
d. Koresponden yang memilih "sangat tidak setuju" sebanyak 0\%

Berdasarkan hasil presentase pernyataan kesepuluh, dapat dilihat bahwa Mitra mendapatkan manfaat langsung dari kegiatan PkM yang dilakasanakan. Hal tersebut dapat dilihat dengan pilihan responden sebesar 28,57\% "sangat setuju", 71,43\% "setuju" dan pilihan tidak setuju dan sangat tidak setuju 0\%. Nilai presentasi juga divisualisasikan melalui gambar 10. 
Gambar 10. Mitra mendapatkan manfaat langsung dari kegiatan PkM yang dilakasanakan

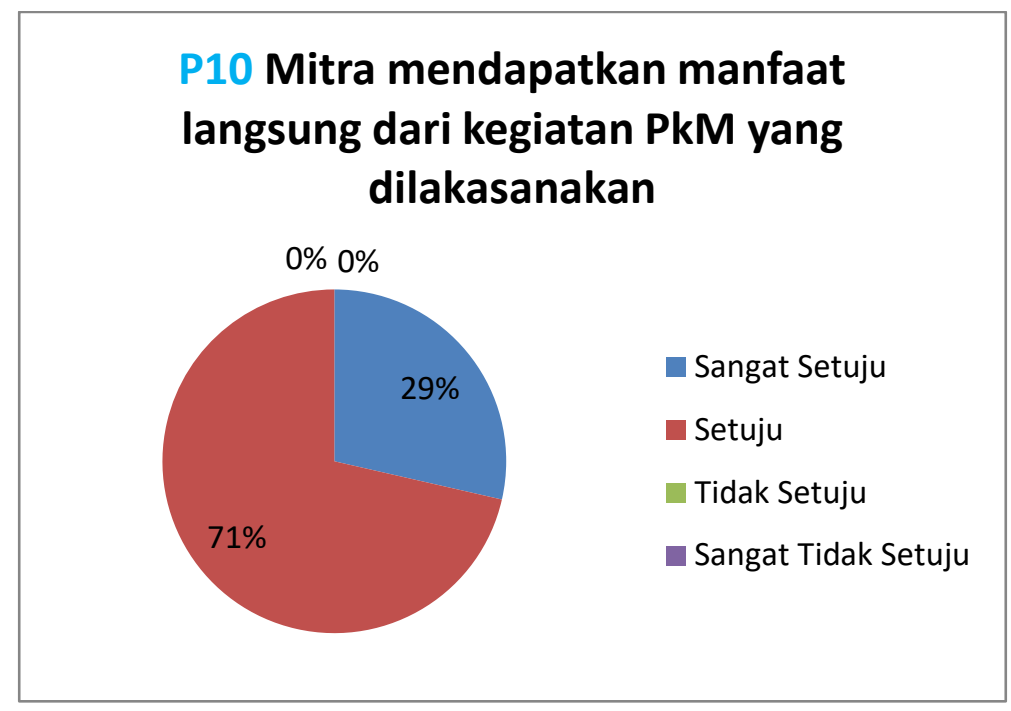

Selanjutnya, pernyataan kesebelas terkait kegiatan $\mathrm{PkM}$ berhasil meningkatkan kesejahteraan/kecerdasan Mitra, hasil kuesioner sebagai berikut.

11. Kegiatan PkM berhasil meningkatkan kesejahteraan/kecerdasan Mitra
a. Koresponden yang memilih "Sangat Setuju" sebanyak 14,28\%
b. Koresponden yang memilih "setuju" sebanyak $85,71 \%$
c. Koresponden yang memilih "tidak setuju" sebanyak $0 \%$
d. Koresponden yang memilih "sangat tidak setuju” sebanyak 0\%

Berdasarkan hasil presentase pernyataan kesebelas, dapat dilihat bahwa kegiatan PkM berhasil meningkatkan kesejahteraan/kecerdasan Mitra. Hal tersebut dapat dilihat dengan pilihan responden sebesar 29,01\% "sangat setuju", 70.99\% "setuju" dan pilihan tidak setuju dan sangat tidak setuju $0 \%$. Nilai presentasi juga divisualisasikan melalui gambar 11.

Gambar 1l. Kegiatan PkM berhasil meningkatkan kesejahteraan/kecerdasan Mitra

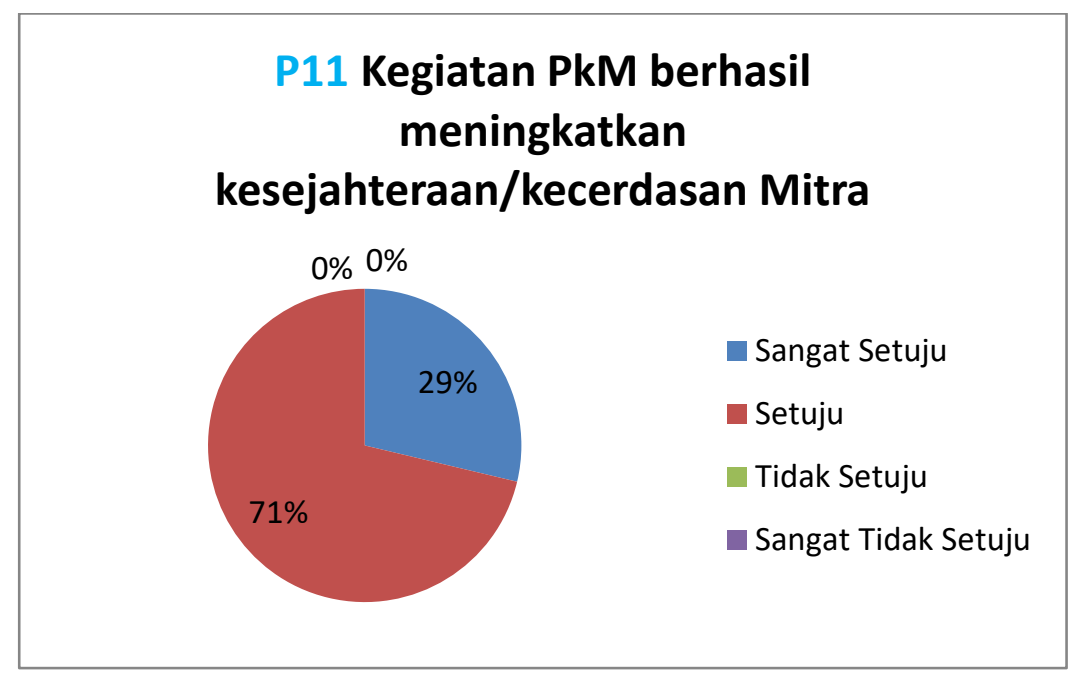


Selanjutnya, pernyataan kedua belas terkait kegiatan seacara umum, mitra puas terhadap kegiatan PkM, hasil kuesioner sebagai berikut.

12. Secara umum, mitra puas terhadap kegiatan PkM

a. Koresponden yang memilih "Sangat Setuju” sebanyak $11 \%$

b. Koresponden yang memilih "setuju" sebanyak $89 \%$

c. Koresponden yang memilih "tidak setuju" sebanyak $0 \%$

d. Koresponden yang memilih "sangat tidak setuju" sebanyak $0 \%$

Berdasarkan hasil presentase pernyataan kesebelas, dapat dilihat bahwa kegiatan PkM berhasil meningkatkan kesejahteraan/kecerdasan Mitra. Hal tersebut dapat dilihat dengan pilihan responden sebesar $11 \%$ "sangat setuju”, $89 \%$ "setuju" dan pilihan tidak setuju dan sangat tidak setuju $0 \%$. Nilai presentasi juga divisualisasikan melalui gambar 12.

Gambar 12. Pl2 Secara umum, mitra puas terhadap kegiatan PkM

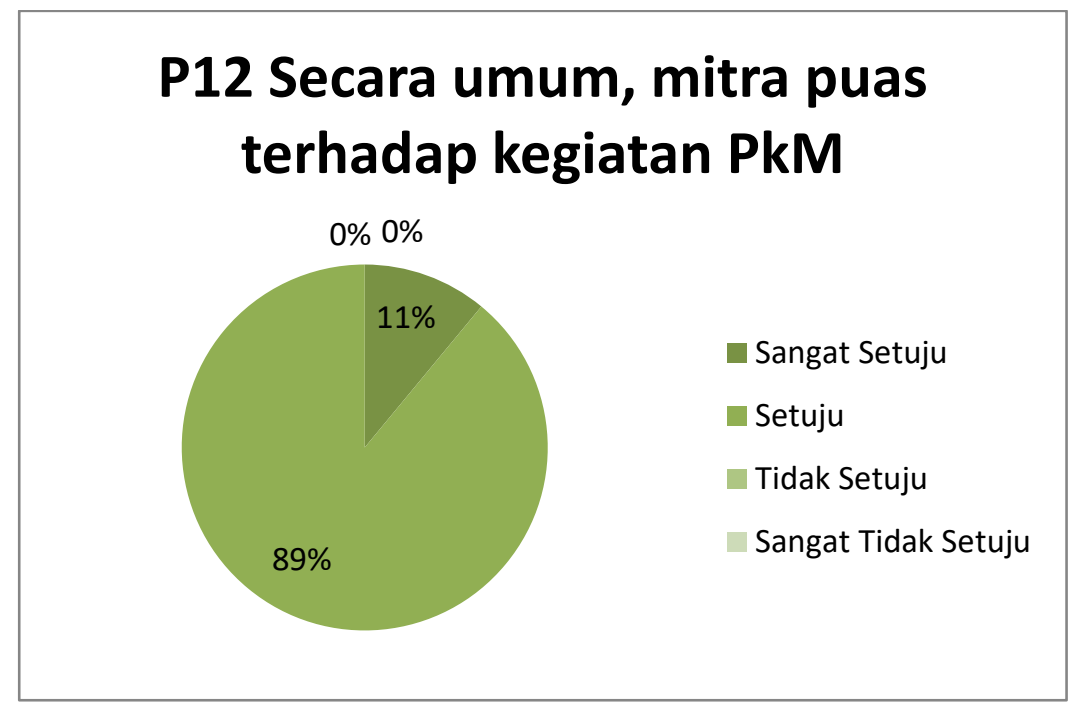

Berdasarkan hasil angket kepuasan mitra terhadap kegiatan pengabdian kepada masyarakat berupa pelatihan penulisan artikel, dengan guru-guru MGMP Bahasa Indonesia SMP se-Kota Pekanbaru berhasil dan sukses, karena mitra/peserta merasa puas dengan pelayanan yang diberikan oleh Tim pengabdian baik dari segi materi PkM sesuai dengan kebutuhan mitra/peserta sampai tahap kegiatan PkM yang berhasil meningkatkan kecerdesan mitra/peserta. Oleh karena itu, tim PkM Universitas Islam Riau berhasil mencapai target yang ditentukan sebelumnya.

\section{Conclusion}

Berdasarkan hasil dan pembahasan adapun simpulan pelatihan penulisan artikel ilmiah bagi guru-guru MGMP Bahasa Indonesia SMP se-Kota Pekanbaru dapat meningkatnya pemahaman guru dalam membuat artikel ilmiah, serta mampu menulis artikel ilmiah dan memublikasikannya pada jurnal-jurnal tidak terakreditasi, terakreditasi maupun bereputasi. Berdasarkan hasil PkM guru-guru MGMP Bahasa Indonesia SMP se-Kota Pekanbaru dapat dinyatakan beberapa saran terkai pelatihan yang telah dilakukan. Adapun saran-saran yang dimaksud adalah sebagai berikut. 
1. Perlu perhatian steakholder agar guru-guru MGMP Bahasa Indonesia SMP se-Kota Pekanbaru selalu mendapatkan workshop/pendampingan secara berkesinambungan terkait penuliasn artikel.

2. Diharapkan instansi sekolah atau pendidikan terkait memiliki sebuah jurnal, sehingga guruguru tidak perlu mencari jurnal yang lainnya untuk keperluan publikasi.

3. Guru-guru sebaiknya selalu mengikuti workshop terkait penulisan artikel.

4. Guru-guru harus lebih giat lagi melakukan penelitian dan memublikasi hasil penelitiannya di berbagai jurnal yang ada di dalam maupun luar negeri.

\section{Bibliography}

Alber, A., \& Hermaliza, H. (2021). An Error Analysis of Semantic Level in Roau Newspaper Articles. Kata: Penelitian Tentang Ilmu Bahasa Dan Sastra, 5(2), 253-269.

https://doi.org/10.22216/kata.v5i2.429

Andriyani, N., Fatmawati, F., Erni, E., Alber, A., \& Nst, W. E. P. (2021). Pelatihan Penggunaan Media Sosial Facebook sebagai Media Pembelajaran Inovatif di SMAN 2 Pekanbaru. Jurnal Implementasi, l(2), 92-95. http://jurnalilmiah.org/journal/index.php/ji/article/view/30

Depdiknas. (2015). Undang-Undang Republik Indonesia Nomor 14 Tahun 2015 tentang Guru dan Dosen. Jakarta: Depdiknas.

Dewi, P. K., Rizal, M. S., Ardhian, D., \& Hardinata, V. (2017). Pelatihan Penulisan Artikel Ilmiah Berbasis Penelitian Tindakan Kelas pada Guru SMP. Jurnal ABDI, 2(2), 7. https://doi.org/10.26740/ja.v2n2.p7-17

Djuroto, T., \& Suprijadi, B. (2005). Menulis Artikel dan Karya Ilmiah. Bandung: Remaja Rosdakarya.

Jatmiko, W., Santoso, H. B., Purbarani, S. C., Sulistyo, A. R., Purnomo, D. M. J., Firmansyah, D., Yusuf, M., MOA, Q. A. M. O. A., \& Laili, N. A. (2015). Paduan Penulisan Artikel Ilmiah. Jakarta: Fakultas Ilmu Komputer Universitas Indonesia.

Maimunah, S. A. (2007). Buku Pintar Bahasa Indonesia. Jakarta: Prestasi Pustaka Publisher.

Marwoto, P., Sopyan, A., Linuwih, S., \& Subali, B. (2013). Peningkatan Kemampuan Menulis Artikel Ilmiah Sains Guru Sekolah Dasar Melalui Kegiatan Pengabdian Masyarakat. Jurnal Abdimas, 17(2), 11l-116. https://journal.unnes.ac.id/nju/index.php/abdimas/article/view/10300/6401

Ngabiyanto, N., Saputro, I. H., Pramono, Di., \& Lestar, E. Y. (2021). Pelatihan Optimalisasi Model Pembelajaran Student Centered Learning melalui Pelatihan Penulisan Artikel Ilmiah. Implementasi, l(1), 16-2l. http://jurnalilmiah.org/journal/index.php/ji/index\%0APelatihan

Ningsih, S. C., \& Aviory, K. (2020). Pendampingan Penulisan Artikel Ilmiah bagi Guru SD. International Journal of Community Service Learning, 4(2), 109-116. https://ejournal.undiksha.ac.id/index.php/IJCSL/article/view/19439

Noorjannah, L. (2015). Pengembangan Profesionalisme Guru melalui Penulisan Karya Tulis Ilmiah Bagi Guru Profesional di SMA Negeri 1 Kauman Kabupaten Tulungagung. Jurnal Humanity, 10(1).

Slameto. (2015). Rasional dan Elemen Perubahan Kurikulum 2013. Jurnal Scholaria, 5(1), 1-9.

Slameto, S. (2016). Penulisan Artikel Ilmiah Hasil Penelitian Tindakan Kelas. Scholaria : Jurnal Pendidikan Dan Kebudayaan, 6(2), 46-57. https://doi.org/10.24246/j.scholaria.2016.v6.i2.p46-57

Supriyadi. (2013). Menulis Karya Ilmiah dengan Pendekatan Konstruktivisme: Pembelajaran Menulis Karya Ilmiah 
yang Inovatif dan Konstruktif. Gorontalo: UNG Press Gorontalo.

Suyanto, \& Asep, J. (2014). Cara Cepat Belajar Menulis Karya Ilmiah. Yogyakarta: Multi Presindo.

ZA, T. (2020). Menulis Artikel Ilmiah untuk Jurnal. Education Zone, August 2018.

https://doi.org/10.31219/osf.io/24v7t 